\title{
Assessment of analytical techniques for characterization of crystalline clopidogrel forms in patent applications
}

\author{
Luiz Marcelo Lira, ${ }^{1,2, *}$, Alexandre Lopes Lourenço², Guilherme Ferreira Neves', \\ Valéria Pereira de Sousa ${ }^{1}$, Carlos Rangel Rodrigues ${ }^{1}$, Lúcio Mendes Cabral ${ }^{1}$
}

\begin{abstract}
${ }^{1}$ Laboratory of Industrial Pharmaceutical Technology, Faculty of Pharmacy, Federal University of Rio de Janeiro, Rio de Janeiro, RJ, Brazil, ${ }^{2}$ Brazilian National Institute of Industrial Property, Rio de Janeiro, RJ, Brazil
\end{abstract}

\begin{abstract}
The aim of this study was to evaluate two important aspects of patent applications of crystalline forms of drugs: (i) the physicochemical characterization of the crystalline forms; and (ii) the procedure for preparing crystals of the blockbuster drug clopidogrel. To this end, searches were conducted using online patent databases. The results showed that: (i) the majority of patent applications for clopidogrel crystalline forms failed to comply with proposed Brazilian Patent Office guidelines. This was primarily due to insufficient number of analytical techniques evaluating the crystalline phase. In addition, some patent applications lacked assessment of chemical/crystallography purity; (ii) use of more than two analytical techniques is important; and (iii) the crystallization procedure for clopidogrel bisulfate form II were irreproducible based on the procedure given in the patent application.
\end{abstract}

Uniterms: Clopidogrel/crystalline forms/physicochemical characterization. Clopidogrel/crystalline forms/patents. Polymorphism.

\begin{abstract}
Este trabalho tem como objetivo avaliar dois aspectos importantes em um pedido de patente de formas cristalinas de fármacos: (i) caracterização físico-química das formas cristalinas e (ii)o procedimento de preparo da forma II do fármaco clopidogrel, um blockbuster de vendas. Realizaram-se buscas em bancos de dados patentários on line. Os resultados mostraram que (i) a maioria dos pedidos de patente de formas cristalinas do clopidogrel não se adequam com proposta do INPI devido ao número insuficiente de técnicas analíticas utilizadas na caracterização da fase cristalina. Ainda, em alguns pedidos de patente não há a presença da avaliação da pureza química/cristalográfica; (ii) a importância de se utilizar mais de duas técnicas de avaliação e (iii) que não foi possível a reprodução da cristalização com o procedimento apresentado no pedido de patente.
\end{abstract}

Unitermos: Clopidogrel/forma cristalina/caracterização físico-química. Clopidogrel/forma cristalina/ patentes. Polimorfismo.

\section{INTRODUCTION}

Patents are one of the most effective tools for researchers, whether individuals or corporations, to protect their investments and secure temporary marketing exclusivity of an invention. Currently, the pharmaceutical industry is one of the most frequent users of the international patent system (Correa, 2007; Cabri et al., 2006). This has been especially true after the signing of the Agreement on Trade-Related Aspects of Intellectual Property Rights

*Correspondence: L. M. Lira. Instituto Nacional da Propriedade Industrial. Rua São Bento, n.1. Centro, 20090-010 - Rio de Janeiro - RJ, Brasil. E-mail: liraml@inpi.gov.br
(TRIPS) on April 15 th 1994 , during the last meeting of the General Agreement on Tariffs and Trade (GATT) study group. This agreement established minimum levels of protection for inventions across all technology fields for signatories of the World Trade Organization (WTO).

With the decline in the number of patent applications for new molecular entities, the pharmaceutical industry increasingly relies on so-called "incremental innovations", i.e., requests for privileges of secondary issues regarding the initial invention (usually molecular entities). This is especially the case for true polymorphs, amorphous and solvatomorphic forms of a known compound already revealed in the prior art. This kind of patent applications 
can lead to an extension of patent protection, which is known as evergreening, a widely used business strategy (Bansal et al, 2009; Plaza De Avila, 2007; Mitssuchi, 2009; Correa, 2006; Burdon, Sloper, 2003; Lerma, 2007).

One type of incremental innovation in the pharmaceutical area involves the discovery of amorphous and/or polymorphic forms of known compounds. Polymorphism is a property displayed by some organic or inorganic molecules that can exist in multiple crystal forms with different arrangements / conformations of their respective crystal lattices (Grant, 1999). Molecular entities demonstrate two kinds of crystalline systems: the single-component (anhydrous/non solvated forms) and multi-component (solvatomorphs, salts and cocrystals). Although the Food and Drug Administration (FDA) states that co-crystals are a type of Active Pharmaceutical Ingredient (API)-excipient blend, these systems may converge and produce different polymorphic forms (Aitipamula et al, 2012; FDA, 2013). Since polymorphs have different molecular arrangements, they carry different energies, which affect various important physicochemical properties such as reactivity, solubility, compressibility and flow (Vippagunta, Brittain, Grant, 2001). It is generally accepted that when developing a pharmaceutical form, the lower energy crystalline lattice is the most stable form and helps to avoid degradation and polymorphic transitions. However, there are some exceptions in which a less stable form is used for its increased solubility (Singhal, Curatolo, 2004).

The physicochemical characterization of molecules in the phase is common practice in the state of the art and it is currently acknowledged that various analytical techniques should be used concomitantly for the identification of polymorphic forms (Vippagunta, Brittain, Grant, 2001; Yu, Reutzel, Stepheson, 1998; Byrn et al., 1995; Suryanarayanan, 1995; Brittain, 1995). The literature unanimously describes single crystal X-ray diffraction (SCXRD) as the primary analytical technique used for the physical characterization of crystalline phases. This technique yields important molecular details: including unit cell parameters, molecular density and conformation. However, powder X-ray diffraction (PXRD), solid phase spectroscopy (Infrared spectroscopy - IR, with or without Fourier transformation (FTIR), Raman spectroscopy, ${ }^{13}$ carbon solid state nuclear magnetic resonance $-{ }^{13} \mathrm{CSSRMN}$ ), thermal analysis (Differential scanning calorimetry - DSC, Thermogravimetric Analysis - TGA, among others) and microscopy techniques also assist in providing important information on the nature of polymorphic and amorphous molecules (Vippagunta, Brittain, Grant, 2001).
Recently, the Brazilian National Institute of Industrial Property (INPI) released a draft document entitled Proposed Guidelines for Examination of Patent Applications for New Polymorphic Forms, for public consideration. In the document, the appropriate analytical techniques for the characterization of a polymorphic form in a patent application were outlined: single Crystal X-Ray Diffraction (SCXRD), Powder X-Ray Diffraction (PXRD), Carbon Solid State Nuclear Magnetic Resonance Spectroscopy $\left({ }^{13} \mathrm{CSSRMN}\right)$, infrared or Fourier Transform Spectroscopy (IR; FT-IR), RAMAN Spectroscopy, "hot stage" electron microscopy and thermal analysis: Differential Scanning Calorimetry -DSC, Thermogravimetric Analysis - TGA and Differential Thermal Analysis- DTA.

By evaluating the guidelines proposed by INPI, three decreasing "levels" of acceptance for crystal characterization can be discriminated: 1 - The use of single crystal X-ray diffraction (from the text of the proposal: in the case of a single crystal of the chemical, single crystal XRD is sufficient for the perfect characterization of crystalline structure); 2 - in the absence of " 1 ", powder X-ray diffraction should be employed with the Miller indices of the interplanar spacings (or interplanar spacings calculated from Miller indices), the Bragg's angle reflection and the relative intensities of at least 20 reflections (from the text of the proposal: in the absence of a single crystal of the chemical, the powder XRD method with indexing is the preferred technique that should be used. The following criteria should be used including: the Miller indices of interplanar distances, Bragg's angles and the relative intensities of at least 20 reflections beyond the unit cell parameters); and for 3 - in cases of nonsubmission of these parameters, powder X-ray diffraction must be accompanied by at least two analytical techniques along with an evaluation of sample purity (as quoted directly from the proposal text: where indexing is not provided, it is necessary to present the other parameters described and complementation technique of powder XRD method with at least two other analysis methods, (minimum of two), in addition to proving the purity of the sample) (INPI, 2010).

Patents of polymorphs in the pharmaceutical field have been the subject of debate in regards to academic, scientific and legal views based on the premise that, in developing countries, the granting of incremental patents in the pharmaceutical area results in reduced access to medicines (Correa, 2007; Cabri et al., 2006; Plaza De Avila, 2007; Mitssuchi, 2009; Correa, 2006; Burdon, Sloper, 2003; Lerma, 2007). The WTO discussed the matter in 2001 and prepared a document entitled the 
"Doha Declaration", which was actually a letter of intent that provides for the implementation of all the TRIPS flexibilities related to protecting public health in developing countries in the political sphere (WTO, 2001). In the Polymorphic field, it is hard to determine whether these kind of patents are genuinely derived from the intellectual efforts of the researcher and solve a problem of prior art, or are merely legal tools used as a mechanism to indirectly extend a previously granted patent (the patent of a molecule), and, ultimately, hinder the entry of generic drugs onto the market.

According to the Industrial Property Law (Law 9279/96 of 14 May 1996 - LPI) (Brazil, 1996), the most important articles for technical examination by the INPI of a patent application are the patentability requirements - novelty (Art. 11), inventive step (Art. 13) and industrial application (Art. 15), and also the conditions of the patent application, in particular concerning the sufficiency of disclosure of description (art. 24) and clarity of claims (Art. 25). Among these articles, special attention should be devoted to Articles 11 and 24, since they are essential for differentiation of the prior art and reproduction by others, respectively. According to the LPI, the invention and utility model are considered new when they are not included in the prior art. Concerning the sufficiency of disclosure, the description should clearly and adequately describe the object, to enable reproduction by those skilled in the art and indicate, where appropriate, the best execution method.

Therefore, it is understood that the patent application must provide accurate and sufficient data on the subject for examination by a patent examiner, so that it can be differentiated from the state of the art. Moreover, sufficient disclosure should be considered essential for achieving one of the pillars of the patent system. The technology involved in the invention must be accessible to the general public. Thus, the importance of proper presentation of technical data in patent applications of polymorphs of drugs is emphasized here.

Clopidogrel (methyl (+)-S- $\alpha-(2-$ chlorophenyl$4,5,6,7$-tetrahydrothiene[3,2-c] pyridine-5-acetate) is a potent antiplatelet and antithrombotic drug, that was released onto the market after a clinical study demonstrated that it had superior efficacy in preventing thrombotic events when compared to aspirin (myocardial infarction and stroke number) (Clement, 1996). Clopidogrel is an ADP binding inhibitor of platelets via P2Y12 (Herbert, Savi, 2003). This drug has two enantiomers and the active form is $\mathrm{S}-(+)$-clopidogrel and requires hepatic biotransformation to activate its pharmacological activity (Clement, 1996). Clopidogrel is currently marketed as its bisulfate salt (Plavix ${ }^{\circledR}$ ) (Figure 1) in 2008 had worldwide sales worth around 2.616 billion euros (SANOFI, 2012).

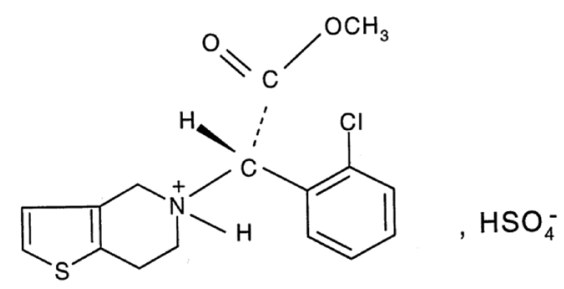

FIGURE 1 - Chemical structure of clopidogrel bisulfate (hydrogenosulfate). Adapted from Bousquet, Castro, SaintGermain, 1999.

The patent applications of crystalline clopidogrel were investigated and analytical techniques for characterization of the crystalline phase assessed according to the guidelines proposed by the INPI. Clopidogrel bisulfate, forms I and II, was obtained from commercial samples and characterized according to the proposed guidelines. Furthermore, attempts to reproduce the preparation of clopidogrel bisulfate form II were undertaken, as described in the PI9911219 Brazilian patent application (Bousquet, Castro, Saint-Germain, 2001). Patent applications of amorphous forms were included in the searches; however, these results were not used for assessing the analytical techniques.

\section{METHODOLOGY}

\section{Search}

The search strategies and experimental methods utilized in this work consisted of: (i) identification of patent applications of the clopidogrel compound (the first patent application disclosing clopidogrel); (ii) identification and evaluation of patent applications pertaining to the polymorphic forms of clopidogrel. For the search (i), the Food and Drug Administration site (FDA, 2012) was used, while for search (ii) the European Patent Office (European Patent Office - EPO) (Espacenet, 2012), INPI site (INPI, 2012) and database ISI web of Knowledge Derwent Innovations Index (Derwent, 2012) were used. These searches were carried out using keywords and by subsequent manual mining of patent applications. The selected patent applications were evaluated to determine whether they fulfilled the acceptance criteria outlined in the proposed INPI guidelines. In this study, the profile of applicants and analytical techniques used to characterize the crystalline phase of the crystalline/polymorphic clopidogrel forms were investigated. 


\section{Characterization of clopidogrel bisulfate polymorphic forms I and II and preparation of form II using the procedure described in the Brazilian patent application PI9911219}

\section{Reagents and chromatography parameters}

The amorphous clopidogrel free base and forms I and II were purchased from Zhejiang Jiuzhou Pharma. All the reagents utilized were of USP grade. The purity of samples used in the characterization techniques and the experimental procedure to produce form II of clopidogrel bisulfate was evaluated using a Shimadzu VP LC-10A VP chromatograph. The chromatographic conditions used for the purity analysis were: C18 column $150 \times 46 \times 5$ microns, UV detection at $220 \mathrm{~nm}$, flow $1.0 \mathrm{~mL} / \mathrm{min}$ with a mobile phase of Phosphate buffer/Acetonitrile in water 75/25 (USP, 2012).

\section{Analytical techniques for characterization of the crystalline phase}

To characterize the polymorphic forms I and II of the commercial clopidogrel bisulfate, PXRD, IR and DSC methods were employed. For PXRD, the sample was finely divided and analyzed on a Rigaku Miniflex X-Ray diffractometer operated at $40 \mathrm{KV}$ and $30 \mathrm{~mA}$. The angle of diffraction range $2 \Theta$ was 2 to 60 at room temperature, and the $\mathrm{X}$-ray source was $\mathrm{CuK} \alpha$ radiation. The IR was performed using a Shimadzu Prestige A210045-21 spectrophotometer with $\mathrm{KBr}$ pellets $1.0 \% \mathrm{w} / \mathrm{w}$ and an absorption region between 4000 and $400 \mathrm{~cm}^{-1}$. DSC was performed using a Shimadzu DSC 60 with a flow rate of $50 \mathrm{~mL} / \mathrm{min} \mathrm{N}_{2}$ and a heating rate of $10^{\circ} \mathrm{C} / \mathrm{min}$ in the range of 25 to $350{ }^{\circ} \mathrm{C}$.
With regards to the experimental procedures used to obtain form II of Clopidogrel bisulfate, the instructions for PI9911219 filed by Sanofi Synthelabo were used. All reagents used for crystallization were of HPLC grade. The crystallization procedure was performed as follows: (i) solubilization of the free base of the drug in acetone P.A. to produce the starting material; (ii); treatment of the free base with $80 \%$ aqueous $\mathrm{H}_{2} \mathrm{SO}_{4} \mathrm{v} / \mathrm{v}$, partial concentration and cooling of the resultant mixture; (iii) - removal of the solid material (referred to as form I); (iv) form II appears spontaneously from the remaining liquid of interest after a waiting period of 3-6 months and temperature not $<40^{\circ} \mathrm{C}$. Variation in the process reflects only the changes in the concentration of the aqueous sulfuric acid used $(96 \% \mathrm{v} / \mathrm{v}$ instead of $80 \% \mathrm{v} / \mathrm{v}$ ).

\section{RESULTS}

\section{Search and evaluation of patent applications of crystalline/polymorphic forms of clopidogrel}

The search strategy used to identify the first patent application of clopidogrel consisted of use of the term "Clopidogrel" as the keyword on the FDA site, orange book section (FDA, 2012). The oldest patent application of a currently US marketed product was the US patent application US4847265 (Badorc, Fréhel, 1989). In the EPO database, searching for the US4847265 family led to the collection of some data from the disclosed/claimed subject matter in the original patent application (first application filed on the same priority date - FR2612929) (Badorc, Fréhel, 1988). In this application, no drug polymorphs were mentioned. The search syntaxes used for this study

TABLE I - Search syntax used in the databases

\begin{tabular}{|c|c|c|c|}
\hline Descriptors & INPI Database & $\begin{array}{l}\text { EPO } \\
\text { Patent database }\end{array}$ & Derwent Innovations Index \\
\hline Search parameters & $\begin{array}{l}\text { Advanced } \\
\text { Search 1-title; Search } \\
\text { 2-summary }\end{array}$ & $\begin{array}{l}\text { Advanced } \\
\text { Field of search "title or } \\
\text { summary" field }\end{array}$ & $\begin{array}{l}\text { Advanced } \\
\text { Entire text search } \\
\text { Chemical section }\end{array}$ \\
\hline $\begin{array}{l}\text { Key words and } \\
\text { Boolean operators }\end{array}$ & $\begin{array}{l}\text { Search syntax: } \\
\text { Clopidogrel AND } \\
\text { (polymorph* OR crystal* or } \\
\text { form* OR thermodynamics* } \\
\text { OR solvate* OR hydrate * } \\
\text { OR amorph*) }\end{array}$ & $\begin{array}{l}\text { Search syntax: } \\
\text { Clopidogrel AND } \\
\text { (polymorph* OR crystal* OR } \\
\text { form* OR thermodynamics* } \\
\text { OR Solvate* OR hydrate* } \\
\text { OR amorph*) }\end{array}$ & $\begin{array}{l}\text { Search syntax: } \\
\text { Search 1: Clopidogrel } \\
\text { Search 2: search 1 AND (Polymorph* } \\
\text { OR Crystal* OR form OR } \\
\text { Thermodynamics* OR Solvate* OR } \\
\text { Hydrate* OR Amorph*); } \\
\text { Search } 2 \text { refined for the } \\
\text { Pharmacology and Pharmacy fields }\end{array}$ \\
\hline
\end{tabular}

* - truncation operator. 
are summarized in Table I. The patent applications retrieved were manually reviewed (without the help of text mining software) in order to remove documents that did not include crystalline/polymorphic forms or that were from the same family, as well as duplicates (by virtue of two searches conducted). Primary results also included the patent applications of the amorphous forms of clopidogrel.

A total of 204 documents were found in the EPO, 426 in Derwent and 24 in the INPI database (09 on title and 13 on summary searches). The results are summarized in Table II. The patent applications excluded concerned the pharmaceutical compositions of clopidogrel, preparation of clopidogrel polymorphs and patent applications outlining new treatment methods. All the documents found on the Derwent database were also present in the EPO database and all the documents found on the "title" search field in the INPI database were again retrieved when the "summary" search was performed.

TABLE II - Quantitative results of clopidogrel polymorphic patent applications

\begin{tabular}{lccc}
\hline Database & $\begin{array}{c}\text { Number of } \\
\text { patents after } \\
\text { search }\end{array}$ & $\begin{array}{c}\text { Number of } \\
\text { patents after } \\
\text { review }\end{array}$ & $\begin{array}{c}\text { Final list after } \\
\text { mining }\end{array}$ \\
\hline EPO & 204 & 24 & \\
DERWENT & 426 & 17 & 24 \\
INPI & 24 & 2 & \\
\hline
\end{tabular}

These results show that the number of patent applications retrieved by the search syntax in the Derwent database was higher than those obtained for the EPO database. However, after mining the contents, the number of patent applications for the crystalline/polymorphic forms was found to be higher in the EPO patent database compared to the Derwent database. These results showed that a search of the patent database using keywords returns a very large number of patent applications that do not involve the matter under assessment. This is because the keywords used may figure in many kinds of clopidogrel patent applications - for example, formulations, analogues and use. However, these broad searches were necessary to retrieve the greatest number of applications possible, particularly due to the fact that in many cases the titles/ abstract of the patent applications do not clearly disclose the patent matter. For example, this can be seen in the patent applications WO2004026879A1 (Cipla Ltd.) (Rao, Kankan, 2004), WO2005080890A1 (Siegfried Generics) (Weber, Levis, Ly, 2005), and WO2008034912A2 (KrkaTovernaZdravil) (Simonic et al., 2008).
Difficulties were encountered retrieving all of the original texts of the patent applications. Therefore, in most cases the equivalent WO filings (by the Patent Cooperation Treaty - PCT - filings) were used for evaluation purposes. Applications not filed via PCT were an exception to this search method, where in this case the original application or some other equivalent online application was used. Table III summarizes all of the patent applications retrieved in this study. Of the 24 patent applications retrieved after mining, there were 03 for which it was only possible to retrieve basic bibliographic data such as title, applicant and the priority date (Piechaczek et al., 2004; Ho et al., 2009a, b).

The results showed that a large number of pharmaceutical companies are primarily developing polymorphs of bisulfate, hydrobromide and hydrochloride salts of $\mathrm{S}-(+)$-clopidogrel, which clearly indicates the search for technological alternatives to the free base and salt of the initially synthesized bisulfate. Of the sixteen different applicants, only the Instytut Farmaceutyczny was not a pharmaceutical company. There was a wide range of applicant nationalities, with representatives from the United States of America (Ivax Corporation), Europe (e.g. Sanofi-Aventis, Ratiopharm GmbH, Zentiva, Generics Limited, Sanofi-Synthelabo, Adamed SP ZOO among others), India (Heterodrugs Ltd., Cadila Healthcare Ltd., Cipla Ltd., Ranbaxy Lab Ltd, SK Chemicals Ltd.) and Israel (Teva Pharmaceuticals).

Another interesting finding is that only 2 of the applicants are listed in the 2011 global executive pharmaceutical ranking prepared by the Executive Pharmaceutical Consultant: Sanofi-Aventis ( $\left.3^{\text {rd }}\right)$ and Teva Pharmaceuticals (12 $\left.{ }^{\text {th }}\right)$ (Pharmaexec.com, 2012). This demonstrates that investment in incremental inventions is a research/market strategy in both big pharma and generic-drug companies. For Clopidogrel, most applicants in Europe and Asia are generics manufacturers, which suggests that they work with the same marketing strategy, i.e., the development of new crystalline forms (plus various new salts and crystalline forms) of a known blockbuster drug. From the data depicted in Figure 2, it can be seen that India has the largest number of filings, followed by France (headquarters of Sanofi) and Israel.

After evaluating the claimed matter present in patent applications, it became clear that huge effort has been invested in order to obtain several crystalline salts in addition to the drug and its polymorphs before expiration of the clopidogrel bisulfate molecule patent. Therefore, several pharmaceutical companies, regardless of their business model, are investing in obtaining new crystalline forms of clopidogrel bisulfate. This also extends to the 
TABLE III - Patent applications for clopidogrel polymorphs retrieved

\begin{tabular}{|c|c|c|c|}
\hline Patent Application & Priority date & Applicant & Principal Claimed Matter \\
\hline $\begin{array}{l}\text { WO9965915A1 (Bousquet, Castro, } \\
\text { Saint-Germain, op cit) }\end{array}$ & $15 / 06 / 1998$ & Sanofi- Synthelabo & Clopidogrel bisulfate form II \\
\hline $\begin{array}{l}\text { WO03051362A2 (Lifshitz-Liron et al, } \\
\text { 2003) }\end{array}$ & $18 / 12 / 2001$ & Teva Pharmaceuticals & $\begin{array}{l}\text { Clopidogrel bisulfate forms III, IV, V and VI; } \\
\text { amorphous clopidogrel bisulfate. }\end{array}$ \\
\hline $\begin{array}{l}\text { WO03066637A1 (Kótay Nagy et al., } \\
\text { 2003) }\end{array}$ & $06 / 02 / 2002$ & $\begin{array}{l}\text { Egys } \\
\text { Gyogyszervegyeszet } \\
\text { Gyar. }\end{array}$ & Clopidogrel hydrochloride, forms I and II \\
\hline $\begin{array}{l}\text { PL355514A1 (Piechaczek et al., 2004, } \\
\text { op cit) }\end{array}$ & $14 / 08 / 2002$ & $\begin{array}{l}\text { Instytut } \\
\text { Farmaceutyczny. }\end{array}$ & No data retrieved \\
\hline $\begin{array}{l}\text { WO2004026879A1 (Rao, Kankan, op } \\
\text { cit) }\end{array}$ & $19 / 09 / 2002$ & Cipla Ltd. & $\begin{array}{l}\text { Amorphous clopidogrel bisulfate; complex } \\
\text { with dissolution enhancer }\end{array}$ \\
\hline $\begin{array}{l}\text { WO2004052966A1 (Narasa et al., } \\
\text { 2004) }\end{array}$ & $09 / 12 / 2002$ & Hete & Clopidogrel bisulfate form III \\
\hline $\begin{array}{l}\text { WO2004081015A1 (Parthasaradhi et } \\
\text { al., 2004) }\end{array}$ & $10 / 03 / 2003$ & Ltd. & idogrel bisulfate \\
\hline $\begin{array}{l}\text { WO2004081016A1 (Lohray et al, } \\
\text { 2004) }\end{array}$ & $12 / 03 / 2003$ & Cadila Healthcare Ltd. & $\begin{array}{l}\text { Amorphous clopidogrel bisulfate and mixtures } \\
\text { with forms I and II }\end{array}$ \\
\hline WO2005026174A1 (Arul, et al, 2007) & $11 / 09 / 2003$ & Generics Limited & Clopidogrel hydrobromide forms 1,2 and 3 \\
\hline $\begin{array}{l}\text { CZ295386B6 (Hajicek, Pihera, } \\
\text { Stepnkova, 2005b) }\end{array}$ & $13 / 01 / 2004$ & Zentiva & Clopidogrel hydrobromide form II \\
\hline $\begin{array}{l}\text { WO2005068471A1 (Hajicek, Pihera, } \\
\text { Stepnkova, 2005a) }\end{array}$ & $13 / 01 / 2004$ & Zentiva & Clopidogrel hydrobromide forms I, II and III \\
\hline $\begin{array}{l}\text { WO2005080890A1 (Weber, Levis, Ly, } \\
\text { op cit) }\end{array}$ & $24 / 02 / 2004$ & $\begin{array}{l}\text { Siegfried Generics Int. } \\
\text { Ag. }\end{array}$ & $\begin{array}{l}\text { Clopidogrel hydrobromide forms A, B, C, D, } \\
\text { E and F. Clopidogrel napsylate forms A and B }\end{array}$ \\
\hline $\begin{array}{l}\text { WO2005117866A1 (Kaznakov, } \\
\text { Veverkova, Veverka, 2005) }\end{array}$ & $01 / 06 / 2004$ & Ivax Corporation & Clopidogrel hydrochloride amorphous form \\
\hline $\begin{array}{l}\text { WO2006034451A2 (Finkelstein, } \\
\text { Arohrime, Tessler, 2006) }\end{array}$ & $21 / 09 / 2004$ & Teva Pharı & $\begin{array}{l}\text { Clopidogrel hydrobromide Forms I, II, III, IV, } \\
\text { V, VI, VII, VIII, IX and X }\end{array}$ \\
\hline EP1674468A1 (Jetti, Gersser, 2006) & $21 / 12 / 2004$ & Ratiopharm GMBH. & $\begin{array}{l}\text { Clopidogrel hydrobromide forms A, B, C, D } \\
\text { and E; Clopidogrel hydrobromide monohydrate } \\
\text { forms Hy-1 and Hy-2 }\end{array}$ \\
\hline $\begin{array}{l}\text { WO2005103058A1 (Lorimer, Ng, } \\
\text { 2005a) }\end{array}$ & $20 / 04 / 04$ & Sano & Clopidogrel hydrobromide forms B, C and D \\
\hline $\begin{array}{l}\text { WO2005103059A1 (Lorimer, Ng, } \\
\text { 2005b) }\end{array}$ & $20 / 04 / 04$ & Sanofi Aventis Co. & $\begin{array}{l}\text { Several polymorphs and hydrates of clopidogrel } \\
\text { 1,5-naphtalenedisulfonate }\end{array}$ \\
\hline $\begin{array}{l}\text { WO200702096A2 (Gangakhedkar, } \\
\text { 2007) }\end{array}$ & $05 / 09 / 2005$ & Ranbaxy Lab. Ltd. & Clopidogrel hydrochloride form III \\
\hline $\begin{array}{l}\text { WO2008034912A2 (Simonic et al., } \\
\text { 2008) }\end{array}$ & $22 / 09 / 2006$ & $\begin{array}{l}\text { Krka Tovarna Zdravil } \\
\text { DD novo. }\end{array}$ & $\begin{array}{l}\text { Several clopidogrel camphor-10-sulfonate } \\
\text { forms; Clopidogrel bisulfate form I; Clopidogrel } \\
\text { hydrochloride form }\end{array}$ \\
\hline EP1903046A1 (Majka et al., 2008) & $25 / 09 / 2006$ & Adamed SP ZOO. & Clopidogrel 5- sulfosalicylic acid forms I and II \\
\hline $\begin{array}{l}\text { WO2008046792A1 (Majka, Sawicki, } \\
\text { Trizepal, 2008) }\end{array}$ & $17 / 10 / 2006$ & Adamed SP ZOO. & Racemic clopidogrel polymorph \\
\hline $\begin{array}{l}\text { WO2008108742A2 (Veverka et al., } \\
\text { 2008) }\end{array}$ & $08 / 03 / 2007$ & $\begin{array}{l}\text { Krka Tovarna Zdravil } \\
\text { DD novo. }\end{array}$ & $\begin{array}{l}\text { Clopidogrel hydrobromide forms } \alpha, \beta \text {, and } \gamma \\
\text { Amorphous clopidogrel hydrobromide }\end{array}$ \\
\hline$\overline{\text { KR20090004268A (Ho et al., 2009a) }}$ & $06 / 07 / 2007$ & SK Chemicals CO Ltd. & No data retrieved \\
\hline KR20090004269A (Ho et al., 2009b) & $06 / 07 / 2007$ & SK Chemicals CO Ltd & No data retrieved \\
\hline
\end{tabular}




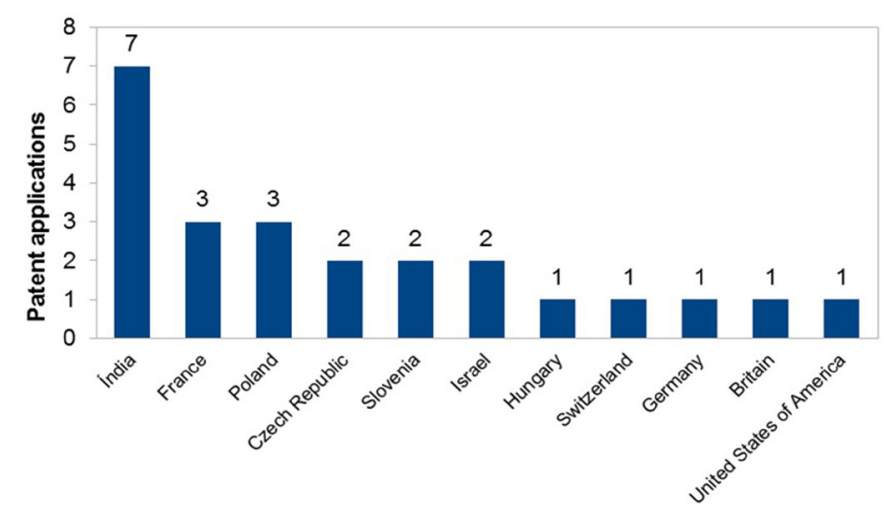

FIGURE 2 - Nationality of applicants in patent applications for clopidogrel crystalline forms.

development of new crystalline salts and polymorphic forms as alternatives to clopidogrel bisulfate for use in future medicines. In summary: clopidogrel bisulfate (Bousquet, Castro, 1999; Lifshitz-Liron et al., 2003; Narasa, et al., 2004), clopidogrel hydrochloride (Kótay Nagy et al., 2003); Gangakhed-Kar, 2007), clopidogrel hydrobromide (Arul et al., 2005; Hajicek, Pihera, Stepankova, 2005a,b; Finkelstein, Aronhime, Tessler, 2006; Weber, Levis, Ly, 2005; Jetti, Griesser, 2006; Lorimer, Ng, 2005a; Veverka et al., 2008), clopidogrel hydrobromide hydrate (Finkelstein, Aronhime, Tessler, 2006), clopidogrel hydrobromide monohydrate (Jetti, Griesser, 2006), clopidogrel napsylate (Weber, Levis, Ly, 2005), clopidogrel camphor-10-sulfonate (Simonic et al., 2008), naphthalene 1,5- disulfonate of clopidogrel and its hydrates/solvates (Lorimer, $\mathrm{Ng}, 2005$ b), sulfosalicylate of clopidogrel (Majka et al., 2008), Monohydrate racemic Clopidogrel (Ho et al., 2009a,b), racemate of clopidogrel free base (Majka, Sawcki, Trzepalka, 2008), and further applications of different amorphous clopidogrel salt forms (Rao, Kankan, 2004; Piechaczek et al., 2004; GangakhedKar, 2007; Veverka et al., 2008); Parthasaradhi et al., 2004; Kaznanov, Veverkova, Veverka, 2005) and mixtures of amorphous forms with polymorphic forms (Lohray et al., 2004). Only 02 patent applications were filed in Brazil, the equivalent to WO9965915 (PI9911219, Bousquet, Castro, Saint-Germain, 2001) and WO2005103058 (PI0509997, Lorimer, Ng, 2005a), both matters patented by Sanofi-Aventis.

The results show that clopidogrel polymorphs have overlapping nomenclatures and likely, redundancies in their subject matter. This fact is due to the difficulty of establishing consistent nomenclature for polymorphic forms in the current literature. Furthermore, as a patent application is published only 18 months after filing, the nomenclature used by the inventors tends to overlap. Thus, it is extremely important that the results of crystalline phase analysis and physico-chemical properties of crystalline forms are included. The technical patent examination by the patent office can be clear and fast only with reliable subject matter disclosed in a patent application.

\section{Assessment of analytical techniques for characterizing crystalline/polymorphic forms in clopidogrel patent applications}

A total of 18 of the 24 patent applications for cclopidogrel were evaluated (amorphous patent applications were excluded). In Figure 3, the results regarding the number of times the analytical techniques were used in the patents of the clopidogrel forms are plotted. PXRD was found to be the most widely used technique for the characterization of crystalline forms, followed by thermal and spectrometric techniques. HPLC remains the standard technique used to evaluate the chemical purity of the crystallized drugs; however, elementary analysis and gas chromatography (GC) were also employed. SCXRD was found not to be frequently used - only in WO9965915 (Bousquet, Castro, 1999) and EP1674468 (Jetti, Griesser, 2006). The limited use of SCXRD may be explained by the experimental difficulty in obtaining single crystals as well as the limited availability of this equipment.

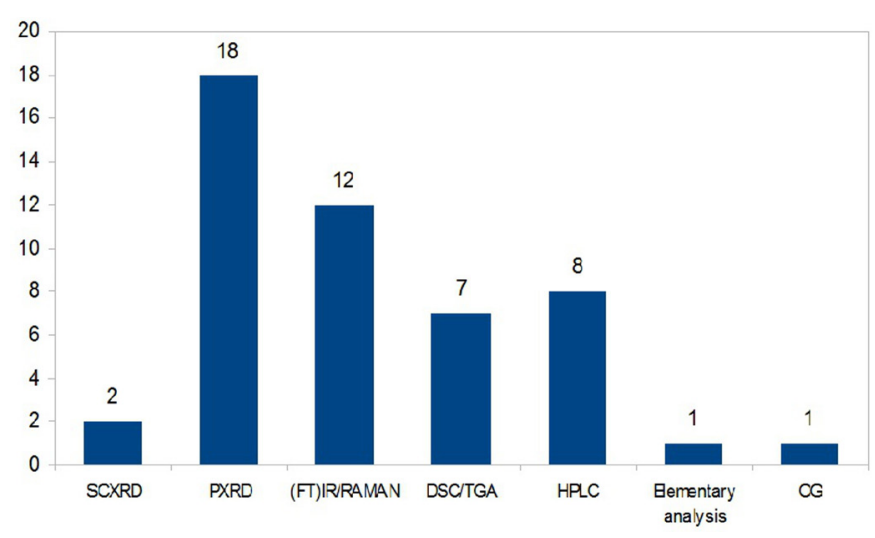

FIGURE 3 - Analytical techniques for characterization of the crystalline phase present in clopidogrel patent applications.

The number of techniques used to characterize crystalline forms of clopidogrel in patent applications is summarized in Figure 4. The results indicated that only 03 patent applications used more than two characterization techniques (one of them being PXRD) and analyzed the chemical purity of the samples. Of the 07 patent applications that demonstrated the use of more than two characterization techniques without purity analysis, two 


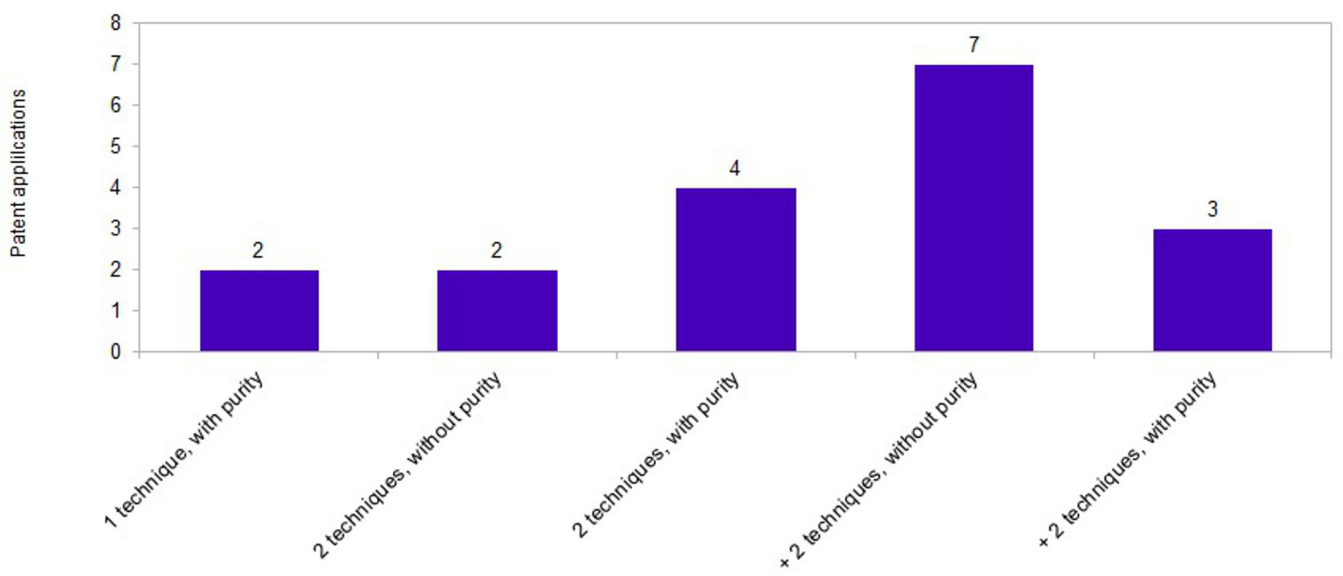

FIGURE 4 - Number of techniques present in patent applications for clopidogrel crystalline forms.

used SCXRD (which presumes a pure single crystal). Therefore, it appears that only 05 Clopidogrel patent applications fulfilled all the proposed guidelines set out by the INPI regarding characterization of polymorphic forms. Patent application PI9911219 is in accordance with the INPI proposed guidelines - it used SCXRD for Bisulfate clopidogrel form II characterization whereas patent application PI0509997 is not in accordance with INPI proposed guidelines. This latter application disclosed three techniques for characterization of polymorphic forms of clopidogrel hydrobromide (PXRD, FTIR and melt point) but no purity analysis was conducted.

The main reasons underlying the non-adequacy of patent applications with regards to the proposed INPI guidelines were: (i) insufficient number of characterization techniques ( 8 patent applications); and (ii) absence of chemical purity analysis of the samples ( 7 patent applications), but also the fact that when PXRD was used, indexation was lacking (angles of reflection, interplanar spacings and relative intensity of peaks were not disclosed in the text) as well as omission of the unit cell parameters (in cases of PXRD use with indexation). All of these crucial factors need to be present in order to ensure the adequacy of patent applications.

\section{Preparation of Clopidogrel bisulfate form II bisulfate based on data provided in patent application PI9911219}

\section{Characterization of clopidogrel bisulfate forms I and II}

Commercial clopidogrel bisulfate samples were purchased and characterized in order to compare them with prior art. The chemical purity of both forms was measured by HPLC and found to be $99.7 \%$ and $99.9 \%$ for forms I and II, respectively. The retention times were found to be 6.3 and $6.7 \mathrm{~min}$ for the two forms, respectively.
Characterization of the crystalline phase for both isoforms was accomplished using PXRD, IR and DSC. For the clopidogrel free base, a content of $99.9 \%$ was obtained by HPLC. Figures 5-7 shows the IR, DSC and PXRD spectra for the commercial clopidogrel bisulfate samples tested.

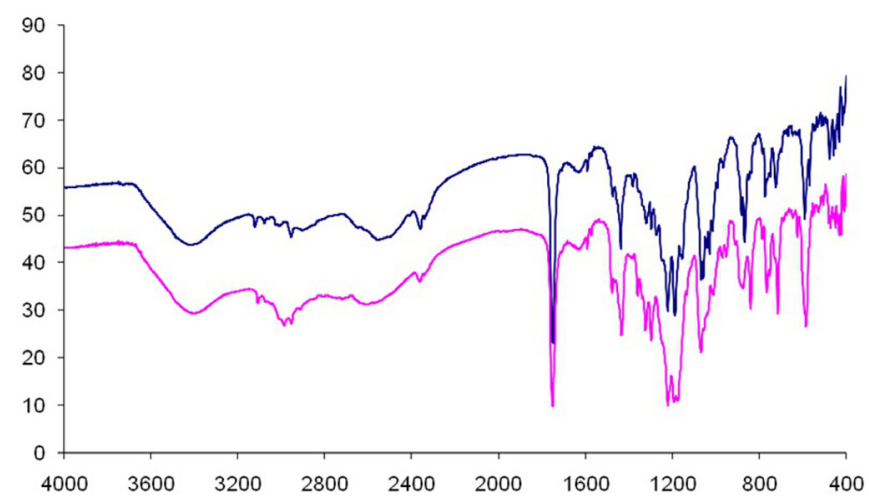

FIGURE 5 - Infrared spectra of clopidogrel bisulfate form I (bottom) and form II (top).

The characterization results of the commercial grade clopidogrel bisulfate samples are summarized in Table 4. These results show that the experimental data of IR and DSC are consistent with that found in the literature (Bousquet, Castro, Saint-Germain, 2001; Koradia, Chawla, Bansal, 2004).

Some discrepancies were found at a specific peak in form I between the matters reported in the patent application versus experimental results and literature data. In the commercial samples and the product analyzed by Koradia (2004), the peak with the greatest intensity was $23.00^{\circ}$ and $23.15^{\circ}$, respectively, while in PI9911219 it was around $9.24^{\circ}$. There were also diffraction peaks at around $9.26^{\circ}$ in the diffractogram patterns of the tested commercial samples and in the material obtained from Koradia (2004). However, these diffraction peaks had 
TABLE IV - Experimental data of IR, PXRD and DSC for the polymorphic forms I and II of clopidogrel bisulfate

\begin{tabular}{|c|c|c|c|c|}
\hline & $\begin{array}{c}\text { Clopidogrel } \\
\text { bisulfate }\end{array}$ & PXRD (characteristic peaks, $2 \theta$ ) & $\begin{array}{l}\text { IV }(\text { characteristic } \\
\left.\text { bands }-\mathrm{cm}^{-1}\right)\end{array}$ & $\operatorname{DSC}\left({ }^{0} \mathrm{C}\right)$ \\
\hline \multirow[t]{2}{*}{$\begin{array}{l}\text { Commercial } \\
\text { Samples }\end{array}$} & Form I & $9.26^{\circ}, 14.39^{\circ}, 23.15^{\circ}$ & $\begin{array}{c}2987 ; 1753 ; 1222 ; 1175 \\
\text { and } 841\end{array}$ & 184.0 \\
\hline & Form II & $8.91^{\circ}, 21.69^{\circ}$ and $23.00^{\circ}$ & $\begin{array}{c}2551 ; 1753 ; 1497 ; 1189 \\
\text { and } 1029\end{array}$ & 178.3 \\
\hline \multirow[t]{2}{*}{$\begin{array}{l}\text { Koradia, Chawla, } \\
\text { Bansal, } 2004\end{array}$} & Form I & $9.26^{\circ}, 14.39^{\circ}, 23.15^{\circ}$ & $2987 ; 1175 ; 841$ & $\begin{array}{c}\text { 181-190, endothermic } \\
\text { peak at } 186\end{array}$ \\
\hline & Form II & $8.91^{\circ}, 12.44^{\circ}, 21.69^{\circ}, 23.00^{\circ}$ & $1497 ; 1189 ; 1029$ & $\begin{array}{c}\text { 177-182, endothermic } \\
\text { peak at } 179\end{array}$ \\
\hline \multirow{2}{*}{$\begin{array}{l}\text { PI9911219 } \\
\text { (Bousquet, Castro, } \\
\text { Saint-Germain, } \\
\text { 2001) }\end{array}$} & Form I & $\begin{array}{l}9.24^{\circ}, 10.93^{\circ}, 18.73^{\circ}, 20.96^{\circ}, \\
23.74^{\circ}, 23.94^{\circ}, 26.22^{\circ}(\text { calculated } \\
\text { from Bragg's Law: } \lambda=2 \text { dsen } \theta)\end{array}$ & $\begin{array}{c}2987,1753,1222,1175, \\
841\end{array}$ & 181.2 \\
\hline & Form II & $\begin{array}{l}12.99^{\circ}, 13.74^{\circ}, 15.80^{\circ}, 17.92^{\circ}, \\
22.03^{\circ}, 24.34^{\circ}, 25.36^{\circ} \text { (calculated } \\
\text { from Bragg's Law: } \lambda=2 \text { dsen } \theta)\end{array}$ & $\begin{array}{c}2551,1753,1497,1189 \\
1029\end{array}$ & 176 \\
\hline
\end{tabular}

less intensity in the diffractogram pattern of PI9911219 (Figure 7). The diffraction pattern obtained for form I of Clopidogrel bisulfate in the IUCr online database was also very similar to the tested commercial samples and those obtained from Koradia (Chernyshev et al., 2010). This may be attributed to the preferred orientation of crystallites in the samples. However, an additional peak of great intensity in a diffraction pattern suggests the presence of sample impurities or mixtures of polymorphs. These results underscore the importance of the physicochemical characterization of crystalline forms using a multi-analytical approach and at best, the assessment of crystallographic purity (phase purity). This finding reinforces the relevance of the proposal introduced by the INPI.

Attempts to reproduce the crystallization process of form II from the description of the process provided in the PI9911219 patent application have met with failure. The experimental procedure was conducted as follows: 4.42 $\mathrm{g}$ of S - clopidogrel free base was dissolved in $20 \mathrm{~mL}$ of acetone. Argon was bubbled into this solution and $1.68 \mathrm{~g}$ was added to $80 \%$ aqueous $\mathrm{H}_{2} \mathrm{SO}_{4}$ while maintaining the temperature below $20^{\circ} \mathrm{C}$. Subsequently, $12 \mathrm{ml}$ of acetone was evaporated under reduced pressure conditions. No changes were observed in the appearance of the solution or profile analysis by thin layer chromatography. The mixture was cooled as described in the patent document and maintained under argon at the same temperature for $48 \mathrm{~h}$. As expected, form I did not undergo precipitation, therefore a new partial evaporation of acetone was conducted and the resultant solution refrigerated for more
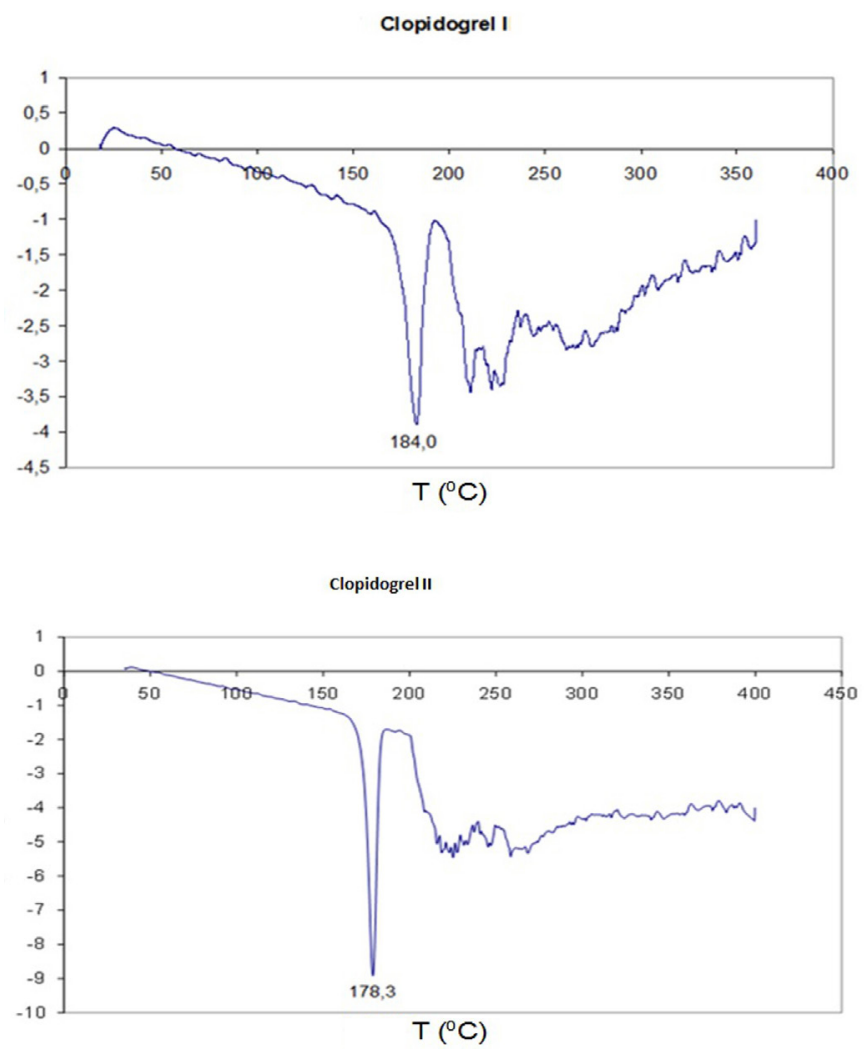

FIGURE 6 - DSC thermograms for forms I (top) and II (bottom) of clopidogrel bisulfate.

than 4 months. Even after this period, no precipitation was observed with either clopidogrel bisulfate isoform.

In addition, the use of $96 \%$ aqueous $\mathrm{H}_{2} \mathrm{SO}_{4}$ did not lead to precipitation from the acetone solution at different 


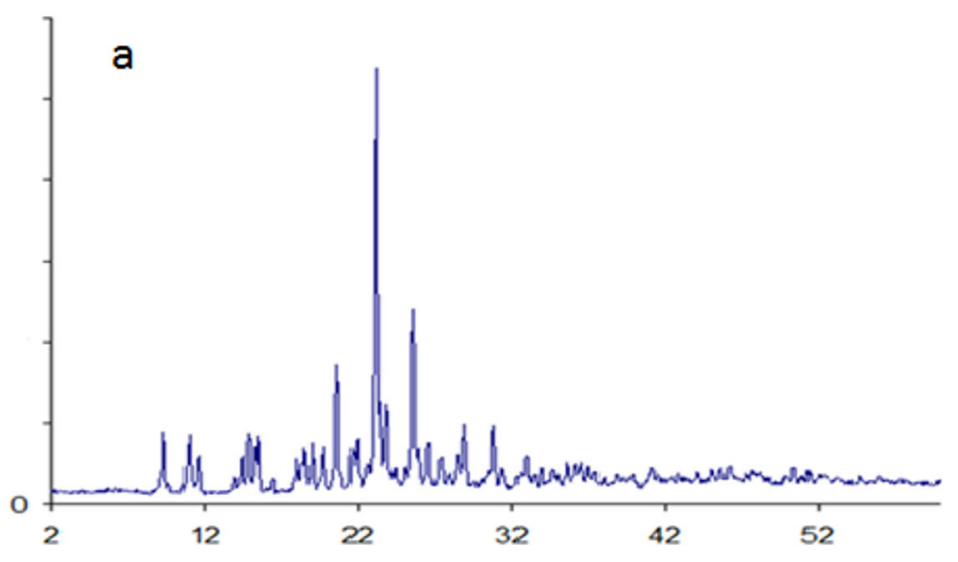

b
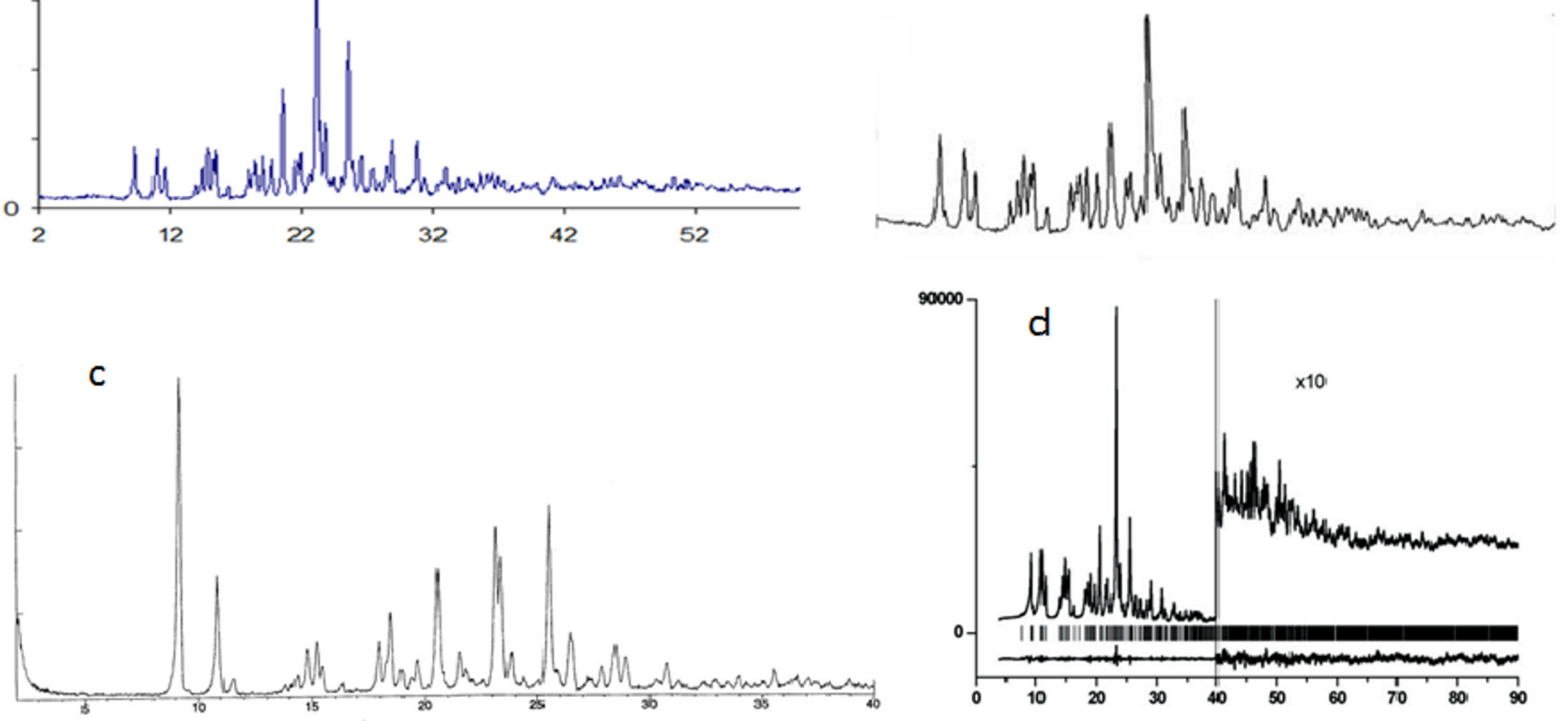

FIGURE 7 - PXRD patterns for form I of clopidogrel bisulfate: a) commercial samples; b) adapted from Koradia, Chawla, Bansal, 2004, c) adapted from PI9911219 - (Bousquet, Castro, Saint-Germain, 2001) and d) adapted from the IUCr database (Chernyshev et al., 2010).

concentrations while being cooled. Use of excess $96 \%$ aqueous $\mathrm{H}_{2} \mathrm{SO}_{4}$ resulted in an intense blackening of the reactional medium. The crystals precipitated after cooling for 48 hours. However, this was a deviation from the procedure described in the patent document. Further studies will be conducted using the described procedures to obtain both crystalline forms of clopidogrel bisulfate.

\section{DISCUSSION}

The pharmaceutical industry has been described in the literature as a major user of the patent system. Thus, the patent is the instrument of choice used by pharmaceutical companies to protect their inventions from exploitation by others. Therefore, since TRIPS does not exclude polymorphs as patentable matter, different countries are free to create technical mechanisms that support patent examinations by the patent office.

The global pharmaceutical market can be considered an oligopoly since mergers of large transnational pharmaceutical companies create an extremely competitive market. In 2000, the ten largest pharmaceutical companies held almost $46 \%$ of the market (Fardelone, Branchi, 2006). In this scenario, it is evident that subject matter claimed in pharmaceutical patents is inherently complex. Incremental innovation provides abundant material for litigation between innovative pharmaceutical corporations and generic manufacturers. Litigation represents a strategic method for companies to obtain indirect extensions of a monopoly of earlier molecule patents whose expiration is imminent ("evergreening"). Such litigation proceedings are detrimental to the entry of generic drugs onto the market, due to the temporal aspects of the judicial process itself and they also create market uncertainty. This theme has been extensively discussed in the literature (Plaza De Avila, 2007; Mitsuuchi, 2009; Correa, 2006; Burdon, Sloper, 2003; Roox et al., 2008; Bernstein, 2002).

In general, the Brazilian LPI does not exclude patentability of crystalline/polymorph forms of drugs. More recently, the proposed guideline set out by the INPI is a first attempt to harmonize the internal procedures for evaluating the patentability of polymorphic forms in the pharmaceutical area. Upon evaluation of the proposed INPI guidelines, it becomes evident that emphasis has 
been placed on the importance of physicochemical characterization of polymorphs in patent applications to assess whether they meet the patent requirements of being novel. Therefore, being novel is an objective requirement and stipulates that patents should not be granted to applications with dubious matter and insufficient information. It is important that the claimed matter can be differentiated from the state of the art.

The present study showed that about $70 \%$ of patent applications of clopidogrel crystalline forms do not have sufficient data for the appropriate characterization of newly developed polymorphic forms set against the state of the art. This is troubling since examination of patent applications by patent examiners from the INPI depends entirely on the matter disclosed in the patent application. Furthermore, the results also showed that SCXRD is not commonly used in patent applications. Another finding was the marked absence of the experimental analysis of chemical purity of the samples in patent applications. None of the patent applications that used PXRD provided all the indexation parameters established in the proposed INPI guidelines (see second provision of proposed guideline). Finally, PXRD is generally considered the definitive technique for crystal characterization. Notably, there is no data in the scientific literature that establishes a minimum number of diffraction peaks in the diffraction pattern (INPI guidelines require at least 20 diffraction peaks). Thus, we suggest that this specific criterion (presence of 20 diffraction peaks) is not essential for the characterization of crystalline/polymorphic forms of drugs since the number of diffraction peaks are proportional to the arrangements found in a crystal lattice.

At the same time, we have experimentally demonstrated the use of various analytical techniques, as described in the proposed INPI guidelines and confirmed that they are necessary for efficient characterization of clopidogrel isoforms. We state that patent applications of crystalline forms of drugs should contain an experimental procedure to assess the crystallographic purity (phase purity) of an isoform that is not the first (as is the case for form II of clopidogrel bisulfate). Furthermore, it was experimentally shown that the procedure specifications of patent application PI9911219 were irreproducible. Consequently, it was not possible to retrieve these polymorphic forms by crystallization of Form II of clopidogrel bisulfate. Although these results are preliminary and require improved experimental procedures, this finding suggests that patent applications of polymorphic forms do not provide sufficient disclosure for reproduction by those skilled in the art.

The data presented in this work demonstrates that preparation of the INPI Proposed Guidelines for Examination of Patent Applications for New Polymorphic Forms is well founded in its design and rationale, since patent applications in the pharmaceutical field do not always contain sufficient technical elements to characterize the various claimed crystalline/polymorphic forms. It is known that a proper patent examination should be conducted in the shortest time possible, while removing the expectation of rights that occurs during the patent application filing process. This can lead to a reduction in litigation by some applicants who end up involved in potential "evergreening" cases. Thus, the initiative taken by the INPI included the devising of rigorous patent exam guidelines that are essential to curb the culture where "poorly drafted patent applications" are often accepted by the current patent system.

The advent of small biotechnology companies is changing the scenario in which pharmaceutical innovation was hitherto restricted to a small number of large corporations. The Brazilian government should consider growth and development of the pharmaceutical area in its strategic plans. Brazil has national pharmaceutical companies, which invest in incremental innovation as an important source of economic and technological development (Bastos, 2005; Shadlen, 2011; Lourenço et al., 2010). The fact that there have been no applications from Brazilian pharmaceutical companies for clopidogrel polymorphs makes it clear that they should consider incremental innovations in the pharmaceutical area as a viable strategy for pharmaceutical industry growth and further reinforces the importance of this topic.

\section{REFERENCES}

AITIMAPULA, S.; BANERJEE, R.; BANSAL, A.K.; BIRADHA, K.; CHENEY, M.L.; CHOUDHURY, A.R.; DESIRAJU, G.R.; DIKUNDWAR, A.G.; DUBEY, R.; DUGGIRALA, N.; GHOGALE, P.P.; GHOSH, S.; GOSWAMI, P.K.; GOUD, N.R.; JETTI, R.R.K.R.; KARPINSKI, P.; KAUSHIK, P.; KUMAR, D.; KUMAR, V.; MOULTON, B.; MUKHERJEE, A.; MUKHERJEE, G.; MYERSON, A.S.; PURI, V.; RAMANAN, A.; RAJAMANNAR, T.; REDDY, C.M.; RODRIGUEZHORNEDO, N.; ROGERS, R.D.; ROW, T.N.G.; SANPHUI, P.; SHAN, N.; SHETE, G.; SINGH, A.; SUN, C.C.; SWIFT, J.A.; THAIMATTAM, R.; THAKUR, T.S.; THAPER, R.K.; THOMAS, S.P.; TOTHADI, S.; VANGALA, V.R.; VARIANKAVAL, N.; VISHWESHWAR, P.; WEYNA, D.R.; ZAWOROTKO, M.J. Polymorphs, salts and cocrystals: what's in a name? Cryst. Growth Des., v.12, p.2147-2152, 2012. 
ARUL, R.; RAWAT, A.S.; GADAKAR, M.; RAO, R.; PISE, A.; GRAY, J. Novel crystalline polymorphs of clopidogrel. WO. Pat.2005026174, 2005.

BANSAL, I.S.; SAHU, D.; BAKSHI, G.; SINGH, S. Evergreening - a controversial issue in pharma milieu. $J$. Intellect Prop. Rig., v.14, p.299-306, 2009.

BADORC, A.; FRÉHEL, D. Enantiomere dextrogyre de 1a-(tetrahydro- 4,5,6,7 thieno (3,2-c) pyridyl-5) (chloro-2 phenyl)-acetate de methyle, son procede de preparation et les compositions pharmaceutiques le renfermant. FR. Pat.2612929, 1988.

BADORC, A.; FRÉHEL, D. Dextro-rotatory enantiomer of methyl alpha-5(4,5,6,7-tetrahydro(3,2-c)thienopyridyl) (2-chlorophenyl)-acetate and the pharmaceutical compositions containing it. US. Pat.4847265, 1989.

BASTOS, V.D. Inovação farmacêutica: padrão setorial e perspectivas para o caso Brasileiro. BNDES setorial, v.22, p.271-296, 2005.

BERNSTEIN, J. Polymorphism in molecular crystals: IUCr monographs on crystallography 14. 1ed. New York: International Union of Crystallography - Oxford Science publications, $2002.410 \mathrm{p}$.

BOUSQUET, A.; CASTRO, B.; SAINT-GERMAIN, J. Forma polimórfica de hidrogenossulfato de clopidogrel, seu método de preparação e composição farmacêutica compreendendo o mesmo. BR. Pat.PI9911219-1, 2001.

BOUSQUET, A.; CASTRO, B.; SAINT-GERMAIN, J. Polymorphic clopidogrel hydrogenesulphate form. WO. Pat.WO9965915, 1999.

BRASIL. Industrial property Brazilian law 9.279 - 14 May 1996. Available at: http://www.inpi.gov.br/index.php/ legislacao/propriedade-intelectual. Accessed on: Mar. 2012.

BRITTAIN, H.G. (Ed.). Physical characterization of pharmaceutical solids. New Jersey: M. Dekker, 1995. v.70, p.140.

BURDON, M.; SLOPER, K. The art of using secondary patents to improve protection. Int. J. Med. Market., v.3, p.226-238, 2003.
BYRN, S.; PFEIFFER, R.; GANEY, M.; HOIBERG, C.; POOCHIKIAN, G. Pharmaceutical solids: a strategic approach to regulatory considerations. Pharm. Res., v.12, p.945-954, 1995.

CABRI, W.; GHETTI, P.; POZZI, G.; ALPEGIANI, M. Polymorphisms and patent, market, and legal battles: cefdinir case study. Org. Process Res. Dev., v.11, p.64-72, 2006.

CHERNYSHEV, S.V.; PIROGOV, S.V.; SHISHKINA, I.N.; VELIKODNY, Y.A. Mnoclinic form I of clopidogrel hydrogen sulfate from powder diffraction data. Acta Cryst, E66, o2101-o2102, 2010. Available at: http://scripts.iucr. org/cgi-bin/paper?S1600536810028783. Accessed on: Aug. 2013.

CLEMENT, G. A randomised, blinded, trial of clopidogrel versus aspirin in patients at risk of ischaemic events (CAPRIE). CAPRIE Steering committee. Lancet, v.348, p.1329-1339, 1996.

CORREA, C.M. Pharmaceutical inventions: when is the granting of a patent justified? Int. J. Intellectual Property Management, v.1, p.4-21, 2006.

CORREA, C.M. Intellectual property and competition law: exploration of some issues of relevance to developing countries, ICTSD IPRs and sustainable development. Programme issue paper. 2007. Available at: http://www. iprsonline.org/resources/docs/corea_Oct07.pdf. Accessed on: Sept. 2011.

DE AVILA PLAZA, C.M.C. Proteção patentária e inovação nas indústrias farmacêuticas: os mecanismos do evergreening e as alternativas do fair followers. In: ARRUDA, G.F.; CERDEIRA, P.C. (Eds.). Propriedade intelectual: novos paradigmas internacionais, conflitos e desafios. São Paulo: Elsevier, 2007. 648 p.

DERWENT Innovation Index. 2012 Available at: http://apps.webofknowledge.com.ez29.periodicos. capes.gov.br/DIIDW_GeneralSearch_input. do?product=DIIDW\&search_mode $=$ GeneralSearch $\&$ SID $=2 \mathrm{~A} 7 \mathrm{~h} 3 \mathrm{H} 5 \mathrm{oCGbK} 31 \mathrm{JO} 88 \mathrm{~m} \&$ preferencesSaved. Accessed on: Mar. 2012.

ESPACENET, number search. 2012 Avaliable at: http:// worldwide.espacenet.com/numberSearch?locale=en_EP. Accessed on: Mar. 2012. 
FOOD AND DRUG ADMINISTRATION. FDA.Orange book: approved drug products with therapeutic equivalence evaluations. 2012. Available at: http://www.accessdata.fda. gov/scripts/cder/ob/default.cfm. Accessed on: Feb. 2012.

FOOD AND DRUG ADMINISTRATION. FDA. Guidance for industry: regulatory classification of Pharmaceutical cocrystals. 2013. Available at: http://www.fda.gov/downloads/ Drugs/GuidanceComplianceRegulatoryInformation/ Guidances/ucm281764.pdf. Accessed on: Aug. 2013.

FARDELONE, L.C.; BRANCHI, B.A. O setor de biofármacos e as oportunidades para o Brasil. Rev. FAE, v.9, p.29-38, 2006.

FINKELSTEIN, N.; ARONHIME, J.; TESSLER, L. Crystalline clopidogrel hydrobromide and processes for preparation thereof. WO. Pat.2006034451, 2006.

GANGAKHEDKAR- KAR, K. Novel polymorphic forms of clopidogrel hydrochloride. WO. Pat.2007029096, 2007.

GRANT, D.J.W. Theory and origin of polymorphism. In: BRITTAIN, H.G. (Ed.). Polymorfism in pharmaceutical solids. New York: Marcel Dekker, 1999. p.1.

HAJICEK, J.; PIHERA, P.; STEPANKOVA, H. New crystalline forms of clopidogrel hydrobromide and methods of their preparation. WO. Pat.2005068471, 2005a.

HAJICEK, J.; PIHERA, P.; STEPANKOVA, H. Clopidogrel hidrobromide in crystalline form II and process for its preparation. CZ. Pat.295386, 2005 b.

HERBERT, J.M.; SAVI, P. P2Y12, a new platelet ADP receptor target of clopidogrel. Semin. Vasc. Med., v.3, p.113-122, 2003.

HO, K.S.; KI, A.E.K.S.; YOUNG, L.J.; HEE, L.M.; JIN, P.Y.; NO, Y.W.; HO, K.N.; HEUNG, S.J.; KYU, L.N.; JU, P.E. Polymorph form I of racemic clopidogrel carboxylic acid monohydrate, and process for the preparation it. KR. Pat.20090004268, 2009a.

HO, K.S.; KI, A.E.K.S.; YOUNG, L.J.; HEE, L.M.; JIN, P.Y.; NO, Y.W.; HO, K.N.; HEUNG, S.J.; KYU, L.N.; JU, P.E. Polymorph form II of racemic clopidogrel carboxylic acid monohydrate, and process for the preparation it. KR. Pat.20090004269, 2009b.
INSTITUTO NACIONAL DE PROPRIEDADE NACIONAL. INPI. Proposta de diretrizes para exame de pedidos de patentes de novas formas polimórficas. 2010. Available at: http://www.inpi.gov.br/menu-esquerdo/patente/discussoestecnicas/polimorfismo/index_html. Accessed on: May 2010 .

INSTITUTO NACIONAL DE PROPRIEDADE NACIONAL. INPI. Banco de dados de patentes. 2012. Available at: http:// www.inpi.gov.br/index.php/patente/busca. Accessed on: Mar. 2012.

JETTI, R.K.; GRIESSER, U. Polymorphs of clopidogrel hydrobromide. EP. Pat.1674468, 2006.

KAZNAKOV, V.; VEVERKOVA, E.; VEVERKA, M. Amorphous clopidogrel hydrochloride and its antithrombotic use. WO. Pat.2005117866, 2005.

KORADIA, V.; CHAWLA, G.; BANSAL, A.K. Qualitative and quantitative analysis of clopidogrel bisulphate polymorphs. Acta Pharm., v.54, p.193-204, 2004.

LERMA, L. Patentabilidad de los compuestos polimórficos. Revista de la Competencia y la Propiedad Intelectual, n.5, p.278-293, 2007. Available at: http://aplicaciones.indecopi. gob.pe/ArchivosPortal/boletines/recompi/castellano/ articulos/primavera2007/LERMA.pdf. Accessed on: Mar. 2012.

LIFSHITZ-LIRON, R.; KOVALEVSKI-ISHAL, E.; WIZEL, S.; AVHAR-MAYDAN, S.; LIDOR-HADAS, R. Polymorphs of clopidogrel hydrogenesulfate. WO. Pat.03051362A2, 2003.

LOHRAY, B.B.; LOHRAY, V.B.; PANDEY, B.; DAVE, M.G. Polymorphs and amorphous form of (S)-(+)-clopidogrel bisulfate. WO. Pat.2004081016, 2004.

LORIMER, K.R.; NG, A.T.F. Clopidogrel salt and polymorphic forms thereof. WO. Pat.2005103058. 2005a.

LORIMER, K.R.; NG, A.T.F. Polymorphic forms of methyl (+) - (s) -alpha- (2-chlorophenyl) -6, 7-dihydrothieno 3,2-c!pyridine-584h) acetate hydrobromide, clopidrogel hydrobromide. WO. Pat.2005103059, 2005 b.

LOURENÇO, A.L.; LIRA, L.M.; CARVALHO, D.P.D.; MELO, P.D.A.; CLÁUDIO DA SILVA, T.S. Gestão das inovações incrementais, o caso omeprazola. Quím. Nova, v.33, n.4, p.1000-1004, 2010. 
MAJKA, Z.; SAWICKI, A.W.; TRZEPALKA, A.; ADAMKIEWICZ, M. New clopidogrel salt and its crystalline forms. EP. Pat.1903046, 2008.

MAJKA, Z.; SAWICKI, A.W.; TRZEPALKA, A. Crystalline form of the racemic methyl- $\alpha$-(2-chlorphenyl)-2-(6,7dihydrothieno [3,2-c]pyridine-5(4h)) acetate, method for the production and use thereof. WO. Pat.2008046792, 2008.

MITSUUCHI, K.V.Y. Patenting pharmaceutical inventions on second uses in Brazil. J. World Intellectual Prop., v.12, p.297-316, 2009.

KÓTAY NAGI, P.; BARKÓCZY, J.; SIMIG, G.; SZENT KIRÁllYI, Z.; GREGOR, T.; FARKAS, B.; VERECZKEYNÉ, D.G.; NAGY, K.; KORTVÉLYESSY, G. Polymorphs of clopidogrel hydrochloride and their use as antithrombic compounds. WO. Pat.03066637, 2003.

NARASA, R.A.; NAGI, R.B.; RATNAKAR, K.R.; RAJI, R.R. A novel polymorph of clopidogrel hydrogen sulfate. WO. Pat.2004052966, 2004.

PARTHASARADHI, R.B.; RATHNAKAR, R.K.; RAJI, R.R.; MURALIDHARA, R.D. Amorphous clopidogrel hydrogen sulfate.WO. Pat.2004081015, 2004.

PHARMEXEC.COM 12 th annual PharmExec 50. 2011. Available at: http://www.pharmexec.com/pharmexec/ article/articleDetail.jsp?id=719596. Accessed on: Mar. 2012.

PIECHACZEK, J.; SERAFIN, J.; MARUSZAK, W.; BALICKI, R.; SZELEJEWSKI, W.; CYBULSKI, M.; MACIEJEWSKI, G.; WYSOCZYNSKA, M.; GLICE, M.; KORCZAK, K. Amorphous form of clopidogrel bisulphate, method of its manufacture and pharmaceutical compounds containing it. PL. Pat.355514. 2004.

RAO, D.R.; KANKAN, R.N. Clopidogrel. WO. Pat.2004026879. 2004.

ROOX, K.; PIKE, J.; BROWN, A.; BECKER, S. Patentrelated barriers to market entry for generic medicines in the European Union. 2008. Available at: http://www. marcasepatentes.pt/files/collections/pt_PT/1/178/EGA\%20 Report\%20IP\%20Barriers\%20Generic\%20Medicines.pdf. Accessed on: Mar. 2012.
SANOFI PRESS RELEASE, 2012. Available at: http://en.sanofi. com/Images/29618_20120208_2011_Results_EN.pdf. Accessed on: Mar. 2012.

SHADLEN, K.C. The political contradictions of incremental innovation: lessons from pharmaceutical patent examination in Brazil. Polit. Soc., v.39, p.143-174, 2011.

SIMONIC, I.; BENKIC, P.; ZUPET, R.; SMRKOLJ, M.; STUKELJ, M. Process for the synthesis of clopidogrel and new forms of pharmaceutically acceptable salts thereof. WO. Pat.2008034912, 2008.

SINGHAL, D.; CURATOLO, W. Drug polymorphism and dosage form design: a practical perspective. Adv. Drug Deliv. Rev., v.56, p.335-347, 2004.

SURYANARAYANAN, R. X-ray powder diffractometry. Drugs and Pharm. Sci., v.70, p.187-187, 1995.

UNITED STATES PHARMACOPEA. USP. National Formulary: USP 35-NF30 - Official Monographs. Clopidogrel bisulfate, p.2733-2734, 2012.

VEVERKA, M.; VEVERKOV, E.; VODNY, S.; SMODIS, J.; SMRKOLJ, M. Polymorphic forms of clopidogrel hydrobromide. WO. Pat.2008108742, 2008.

VIPPAGUNTA, S.R.; BRITTAIN, H.G.; GRANT, D.J. Crystalline solids. Adv. Drug Deliv. Rev., v.48, p.3-26, 2001.

WEBER, B.T.; LEVI, M.K.; LY, H.Q. Pharmacologically acceptable salts of clopidogrel. WO. Pat.2005080890, 2005.

WORLD TRADE ORGANIZATION. WTO. Ministerial conferences - Doha $4^{\text {th }}$ Ministerial - TRIPS declaration. 2001. Available at: http://www.wto.org/english/thewto_e/ minist_e/min01_e/mindecl_trips_e.htm. Accessed on: Mar. 2012.

YU, L.; REUTZEL, S.M.; STEPHESON, G.A. Physical characterization of polymorphic drugs: an integrated characterization strategy. Pharm. Sci. Technol. To., v.1, p.118-127, 1998.

Received for publication on $15^{\text {th }}$ January 2013 Accepted for publication on $06^{\text {th }}$ September 2013 